М.О. Манзяк ${ }^{1}$, Л.В. Крайник ${ }^{2}$ М.Г. Грубель ${ }^{1}$

${ }^{1}$ Начіональна академія сухопутних військ ім. гетьмана П. Сагайдачного, Львів

${ }^{2}$ Національний університет “Львівська політехніка”, Львів

\title{
ТЕНДЕНЦІЇ РОЗВИТКУ КОНСТРУКЦІЙ ПІДВІСОК ВІЙСЬКОВИХ АВТОМОБІЛІВ
}

У статті визначено основні вимоги, які впливають на розвиток конструкцій зразків військової автомобільної техніки (ВАТ). Зокрема встановлено, щзо на підвищення швидкостей руху та мобільності колісної ВАТ при русі бездоріжжям загалом, впливають, як збільшення питомих потужностей двигунів, вибір оптимальних параметрів трансмісії, так і конструкиії підвісок. Вібраційні та коливні навантаження на водія (екіпаж) зразків ВАТ під час руху бездоріжжям формують два визначальні аспекти застосування автомобілів. Перший аспект пов'язаний із штучним обмеженням водієм максимальної швидкості руху нижче технічної максимальної через граничну межу його дискомфорту, а другий - через відповідну втому $і$ суттєве погіршення моторики водія (екіпажу) залежно від тривалості руху бездоріжжям. Визначено тенденцію розвитку конструкцій підвісок, яка полягає у переході від залежних підвісок з нерозрізною балкою осі $і$ жорстким взаємозв'язком кінематики підвісок правого і лівого коліс до незалежних. Такий підхід дозволяє забезпечити підвищення комфортності в русі водія і екіпажу, а також підвищити середні швидкості руху та суттєво зменшити поперечні крени кузова. Проведено аналіз тенденцій впровадження активних $і$ напівактивних підвісок на сучасних зразках колісної ВАТ, щзо дозволяє суттєво покращити комфортність екіпажу, збереженість вантажу та середні швидкості руху. За результатами досліджень встановлено необхідність переходу на довгоходові незалежні підвіски, для зменшення непідресорених мас та вібронавантаженості кузова і екіпажу.

Ключові слова: підвіска, колісна ВАТ, бездоріжж, плавність руху, вібраційні навантаження.

\section{Вступ}

Постановка проблеми. Колісна ВАТ під час виконання бойових завдань експлуатується, як правило, у набагато складніших умовах ніж автомобілі загального призначення. Вона повинна бути більш маневреною при великих швидкостях руху вздовж шляху із значними нерівностями чи, навіть, під час руху вздовж пересіченої місцевості. Тому для формування або підбору параметрів системи підвіски колісної ВАТ та інших систем ставляться набагато жорсткіші вимоги, ніж для автомобілів загального призначення. В епоху сучасних мобільних війн i розвитку конструкцій колісної ВАТ все більшого розповсюдження набувають замість традиційних ресорних і пружинних підвісок нові конструкції, що дозволяють суттєво зменшити віброколивні навантаження на кузов і членів екіпажу та відповідно збільшити швидкості руху - мобільність колісної ВАТ при русі бездоріжжям. Це забезпечується за рахунок автоматики регулювання пружних або демпфуючих характеристик (напівактивні) підвіски або ж одночасної зміни регулювання пружних і демпфуючих характеристик (активні підвіски). Практично це стало характерним для нового покоління тактичних автомобілів у США та інших країн - учасниць блоку НАТО під впливом досвіду нещодавніх військових операцій в Іраку та Афганістані. Відповідні вимоги сформовані у схваленій Конгресом США програмі оновлення парку ВАТ [1].

Аналіз останніх досліджень і публікацій. Нові технічні рішення, що пропонуються закордонними фірмами відносяться в основному до комерційних легкових автомобілів: автоматизація i комп'ютеризація процесів управління; підвищення надійності і удосконалення елементів підвіски; розроблення систем слідкуючої дії із застосуванням електроніки і високоякісних датчиків стану дорожньої поверхні; удосконалення систем піднімання та опускання кузова. Масове застосування таких систем на колісній ВАТ найближчим часом не передбачається.

Деякі закордонні фірми наприклад Bosh (Hiмeччина), пропонують системи управління пневматичною підвіскою для комерційних важких автомобілів. Фірми IVECO Magirus i Volkswagen (Німеччина) передбачають застосування таких систем на військових автомобілях третього покоління [2].

Пневматичною підвіскою 3 електронним управлінням ЕСАC оснащені автомобілі фірми DAF (Голландія) [3].

Найближчим часом прогнозується застосування таких підвісок на окремих серіях колісної BAT [2]. 
На англійському автомобілі Land Rover 100XD легкого класу застосована гідропневматична підвіска, що дозволяє підтримувати кузов автомобіля на одному рівні при русі пересіченою місцевістю i подоланні перешкод. Вказана підвіска забезпечує навіть можливість рухатись за різних рівнів коліс 3 однієї та іншої сторін автомобіля [4]. Звідси випливає доцільність встановлення на шасі таких автомобілів вогневих засобів.

Постійне зростання питомої потужності двигунів ВАТ, за останні 40 років у країнах блоку НАТО - в 2-3 рази, обумовлено прагненням відповідного збільшення мобільності руху бездоріжжям. Слід зауважити, що на сьогодні, середні швидкості переміщення колон ВАТ бездоріжжям у арміях НАТО у 1,5-2 рази вище від аналогічних показників у арміях пострадянських держав. Вказане є характерним і для України та Російської Федерації (РФ), оскільки їх парк ВАТ базується на автомобілях розробки 50 60-х рр. минулого століття (ГАЗ, УРАЛ, ЗиЛ, КАМАЗ, МАЗ). Фактично це ВАТ попереднього покоління у порівнянні із домінуючими у арміях НАТО машинами розробки 1980-х років, як приклад HMMWV M997. Поряд з тим в арміях НАТО, під впливом військових операцій в Іраці та Афганістані, можна констатувати розгортання робіт щодо переходу до нової генерації тактичних автомобілів. Це підтверджується розглядом і прийняттям Конгресом США відповідної програми переозброєння сухопутних військ тактичними автомобілями наступного покоління [1]. Подібні програми створені і у інших країнах, а також спостерігається початок активності у цьому плані і у РФ [1; 5-7].

Мета статті - виходячи 3 аналізу умов застосування зразків колісної ВАТ у збройних конфліктах та розвитку конструкцій підвісок їі перспективних зразків, що експлуатуються в арміях країн НАТО, Китаю, Росії та ін., визначити основні напрямки обгрунтування раціональних конструктивних параметрів підвіски.

\section{Виклад основного матеріалу}

Традиційно базові конструктивні параметри і характеристики підвіски автомобіля загального призначення проектувались 3 умов номінальних навантажень і руху автомобільними дорогами I та II категорій 3 асфальтобетонним покриттям. Повнопривідні модифікації т. зв. автомобілів багатоцільового призначення, що досі складають з часів СРСР основу автомобільного парку ВАТ ЗС України, базувались на максимальній агрегатній комплектації з базовими моделями загального призначення при незначних доповненнях:

- змінами насамперед агрегатів силового приводу - перехід на всі ведучі осі;

- розподільна коробка з пониженим діапазоном в трансмісії;

- односкатна ошиновка з умов прохідності та при необхідності перехід на колісну схему 6х6;

- система централізованого регулювання тиску в шинах і т.п.

Такі доповнення були призначені для покращення опорно-зчіпної прохідності. Однак при русі бездоріжжям окрім опорно-зчіпної прохідності, реальна максимальна швидкість руху обмежується штучно екіпажем зразка колісної ВАТ з умов досягнення граничної дискомфортності руху через надмірні віброколивання, що викликані нерівностями ОП. Ці граничні рівні вібронавантажень та допустимі тривалості їхньої дії на екіпаж без значного впливу на його працездатність відомі і задекларовані у сучасній фаховій літературі по колісній ВАТ [13-36].

Визначальними чинниками розвитку конструкцій ВАТ (тактичних автомобілів) нового покоління, стали широковідомі вимоги протимінного і балістичного захисту, що закладаються ще на початках компонування і робочого проектування нових моделей. Існуюча практика протимінного і балістичного захисту здійснюється шляхом додаткового оснащення вже існуючих машин попереднього покоління засобами захисту з відповідними доробками серійних конструкцій шасі, рами, підвіски і т.д., що суттєво погіршує динаміку руху машин, які не спроектовані під відповідне збільшення повної маси. Ще одним визначальним чинником, стала також умова збільшення максимальних швидкостей руху, у т.ч. при русі бездоріжжям. Це пов'язано з тим, що при русі дорогами 3 твердим покриттям максимальна швидкість руху обмежується насамперед потужністю двигуна і відповідно демонструє стабільну тенденцію зростання, у тому числі і для зразків ВАТ (важких тактичних автомобілів) повною масою 12 40 т, що за останні 50 років змінились з 70-80 км/год до 105-120 км/год (з появою у СРСР КамАЗ-4310) [7-8].

Поряд 3 тим, за умов руху бездоріжжям реального театру бойових дій, основним обмежувальним чинником швидкості руху є гранично допустимі порогові значення віброколивних навантажень. За результатами досліджень виконаних у [9-11] можна стверджувати, що віброколивні навантаження окрім втоми і відчутного зниження фізичної активності екіпажу також мають суттєвий вплив на ефективність ведення бойових дій. Зокрема точність ведення вогню, імовірність ураження цілей, після 6-8 годин віброколивних навантажень під час руху бездоріжжям знижується у 2-2,3 рази у порівнянні з свіжим екіпажем [11].

Відповідно і максимальну швидкість руху ВАТ бездоріжжям у нормативній базі і прикладних комп'ютеризованих програмах розрахунку-оцінки NRMM (англ. NATO Reference Mobility Model), 
обмежують власне граничним рівнем допустимих за тривалістю віброколивних навантажень [12-14]. Одним 3 основних шляхів розвитку конструкцій BAT у цьому аспекті є власне удосконалення підвіски та відповідно пружно-демпфуючих характеристик шин і сидінь екіпажу, вплив яких, є суттєво меншим у порівнянні з підвіскою. Такі зміни конструкцій ВАТ почали втілюватись ще на кращих моделях існуючої 2-ї генерації ВАТ армій НАТО. Це полягає у:

переході від залежних підвісок із нерозрізними балками ведучих осей до незалежних підвісок із значним зниженням непідресорних мас, що має суттєвий вплив на віброколивні навантаження кузова автомобіля і екіпажу, та стійкість руху. Тому що поперечні коливання кузова для бездоріжжя є неоднакові для правого і лівого бортів у залежності від колії машини, висоти впадин мікропрофілю ОП. Класичним прикладом цьому є перехід від залежної ресорної підвіски до незалежної пружної 3 двома поперечними важелями у найбільш масовому для сучасних армії класі ВАT LTV (англ. Light Tactical Vehicle). Автомобілі вказаного класу складають понад 50\% загальної чисельності парку ВАТ розвинутих країн. Показовим у цьому плані $\epsilon$ перехід у США до НMMWV M997/1017 з 1985 року;

суттєвому збільшенню у 1,5-2 рази повного (динамічного) ходу підвіски при переході до незалежних підвісок. 3 аналізу характеристик залежних ресорних підвісок радянських і сучасних російських УАЗ, ГАЗ, ЗиЛ, УрАЛ, КамАЗ, які технічно можна віднести до машин ще попереднього 1-го покоління аналогічних зразків ВАТ НАТО 1950-60 х років випливає, що їх ходи підвіски коливаються у межах 200-250 мм.

Поряд 3 тим на HMMWV M917 та і його наступнику Oshkosh L-ATV значення ходів підвіски коливаються у межах 325-420 мм. Крім того, сучасні вимоги щодо необхідності забезпечення належного балістичного і протимінного захисту зумовили відмову від “безкапотноі” схеми компоновки у середньотонажному (medium) класі, зразки ВАТ типу КамА3 і МАЗ та перехід до “капотної”, “напівкапотної”, як приклад MB Zetros.

Принциповими відмінностями нової генерації BAT, як показує аналіз $[1 ; 5 ; 7 ; 14] \epsilon$ перехід на серійні т. зв. активні і напівактивні системи підвісок, 3 автоматичним чи ручним регулюванням пружних i демпфуючих характеристик. Це дозволяє суттєво підвищити процес гасіння віброколивних збурень від нерівностей бездоріжжя та відповідно підвищити максимальну, з умов комфорту і безпеки, швидкість руху бездоріжжям на відчутні в умовах бойових дій 15-30\%. Промислове розроблення та впровадження активних i напівактивних незалежних підвісок колісної ВАТ у важкому (англ. Heavy) та середньому (англ. Medium) класах започатковано ірландською фірмою Timoney Technology на базі запатентованих у кінці 1990-х р.p. конструктивних рішень [16-18]. Крім того ліцензії на виробництво незалежних підвісок з запатентованими рішеннями у Timoney на початку 2000 років було куплено одним з базових виробників колісної ВАТ для військових потреб Oshkosh L-ATV, як правонаступнику для заміни HMMWV.

Вказана ліцензія також передбачала виготовлення підвісок для нового покоління середніх та важких Oshkosh MTVR HEMTT, для машин виготовлених за програмою MRAP-ATV а також для модернізації частини існуючого парку HMMWV $[1 ; 5 ; 7$; 8]. Показовим є факт, що у 2012 р. керівництво КАМАЗ, враховуючи виконаний МГТУ ім. Н.Е. Баумана патентний огляд і аналіз досліджень у цій сфері [23], проводило переговори 3 Timoney Technology щодо виробництва даного типу підвісок у РФ [24]. Крім того, підвіска Timoney Technology реалізована і у новій генерації 2-4 вісних тактичних машин Rheinmetall Defense i MAN Military Vehicles напр. Wisent Gefas [7]. Відомий виробник ведучих осей Rockwell-Meritor також розгорнув виробництво незалежних напівактивних підвісок під навантаження на вісь до 9 т. за ліцензією Timoney Technology (Volvo, Iveco та інші.).

Конструктивні схеми основних існуючих модифікацій підвіски Oshkosh TAK-4 представлені на рис. 1 [26], а на рис. 2 - типові моделі ВАТ з використанням відповідних модифікацій ТАК-4.

В табл. 1 представлені базові параметри модифікацій підвіски для різних класів бойової маси. максимального навантаження на вісь колісної ВАТ.

Підвіска ТАК-4 та їі модифікація наступної генерації ТАК-4і, що встановлюється на найбільш масових автомобілях армії і корпусу морської піхоти США Oshkosh L-ATV, при ході підвіски 388-420 мм дозволяє забезпечити належну плавність ходу при нелінійних пружних характеристиках підвіски, а у варіанті ТАК-4і автоматичне регулювання - зміну демпфуючих характеристик залежно від характеристик профілю опорної поверхні (бездоріжжя) та швидкості руху.

Фактично ідеї комфортних, активних та напівактивних підвісок для легкових автомобілів престижного класу та автомобілів промисловості (Volvo, Sisu, Zetros) були реалізовані ще наприкінці 1990-х p.p. (гідропневматична підвіска Citroen C5/CX/XM i т.д., яка також $є$ розповсюдженою на автобусах) Однак ці підвіски опрацьовані для асфальтобетонних доріг I і II категорії і амплітуда робочого ходу не перевищує 110-160 мм. Кінематика напрямку пристроїв відповідно, не передбачає швидкий рух бездоріжжям з відповідними ударними навантаженнями. 


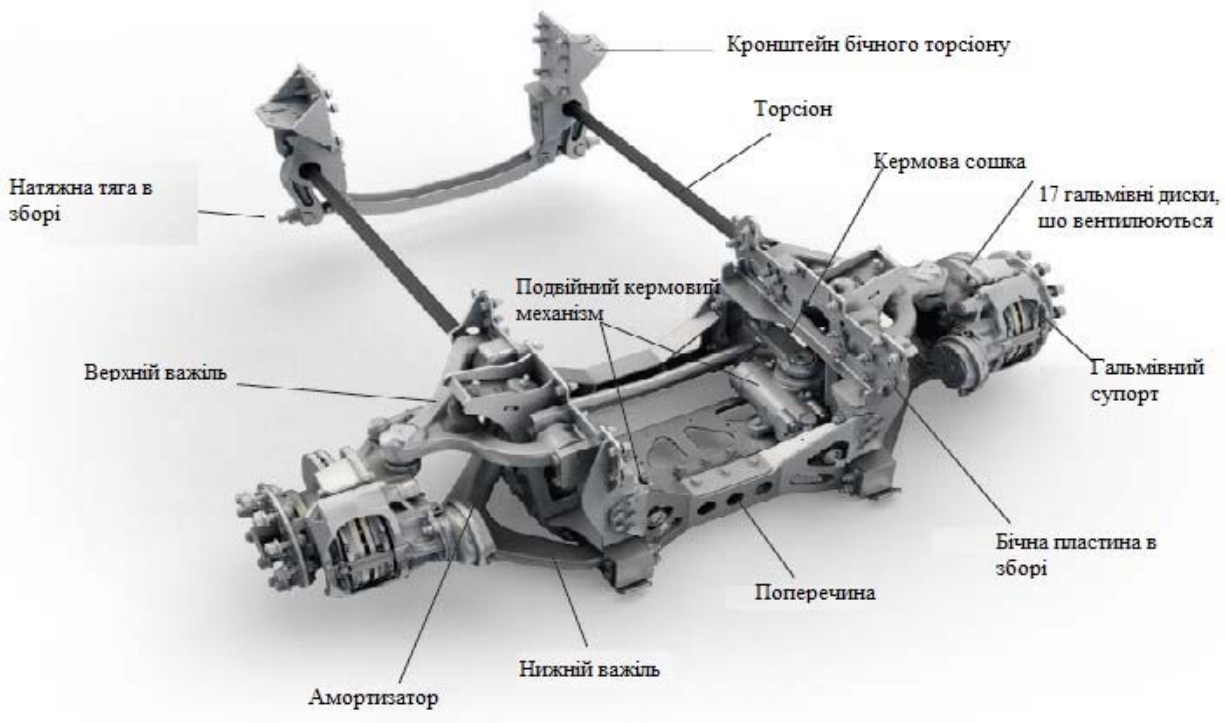

Рис. 1. Конструктивна схема підвіски Oshkosh TAK-4 Джерело: розроблено авторами за даними [24].

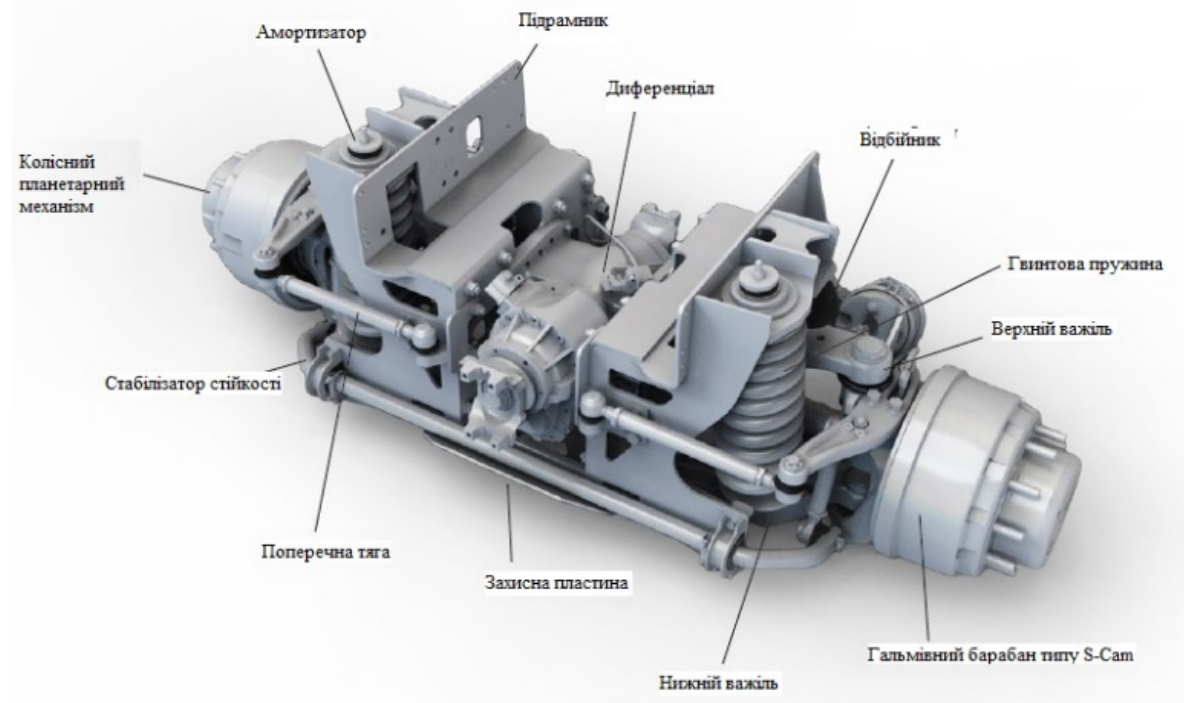

Рис. 2. Типова модель ВАТ з використанням відповідних модифікацій ТАК-4 Джерело: розроблено авторами за даними [24].

Основні параметри модифікацій ТАК-4

\begin{tabular}{|c|c|c|c|c|c|}
\hline $\begin{array}{c}\text { № } \\
\text { з/п }\end{array}$ & Класи & $\begin{array}{c}\text { Важка ВАТ } \\
\text { (heavy) }\end{array}$ & $\begin{array}{c}\text { Середня ВАТ } \\
\text { (medium) }\end{array}$ & $\begin{array}{c}\text { Легка ВАТ } \\
\text { (light) }\end{array}$ & $\begin{array}{c}\text { Модернізація } \\
\text { легкої ВАТ }\end{array}$ \\
\hline 1. & Приклад моделі ВАТ & НЕМТT & MTVR & L-ATV & HMM WV \\
\hline 2. & $\begin{array}{c}\text { Максимальне навантаження на } \\
\text { вісь, кг }\end{array}$ & 12020 & 10430 & н.д.* & 4536 \\
\hline 3. & Максимальний хід підвіски, мм & 406 & 406 & 508 & 356 \\
\hline 4. & Кліренс, мм (Розмір шини) & $421(16 \mathrm{R} 20)$ & $\begin{array}{c}410(16 \mathrm{R} 20 \\
345(395 / 85 / \mathrm{R} 20)\end{array}$ & н.д.** & $433(235 / 80 / \mathrm{R} 20)$ \\
\hline
\end{tabular}

н.д.* - відсутні дані орієнтовно 5000-5500 кг; н.д. * * відсутні дані орієнтовно 470-485 мм.

Джерело: розроблено авторами за даними $[1 ; 3 ; 16 ; 35]$. 
Перехід від залежної підвіски 3 нерозрізною балкою осі і жорстким взаємозв'язком кінематики i динаміки роботи підвісок правого і лівого коліс в умовах руху горбистого бездоріжжя на механічну (пружинну, ресорну чи торсійну) незалежну підвіску, забезпечує підвищення комфортності та, відповідно, середньої швидкості руху на 70-50\%.

Це стало ще $з$ 1980-х р.p. основною причиною популярності важких військових шасі TATRA T815 та іншого ліцензійного виробництва в Індії. Але крім відчутного зменшення непідресорних мас, i суттєвого впливу на вібронавантаженість кузова i екіпажу, незалежна підвіска дозволяє також суттєво зменшити і поперечні крени (поперечно-кутові коливання). Крім того, вона ефективніша при автоматизації регулювання демпфуючих характеристик, як приклад амортизатори 3 автоматикою регулювання - зміни коефіцієнта демпфування, що важливо 3 умов стабілізації контакту шин 3 дорожнім покриттям. Відповідно це впливає на стійкість, керованість руху та реалізацію тягового зусилля.

Наступним етапом розвитку є повна, заміна або доповнення, сучасні моделі TATRA T815 для військової сфери, механічного пружного елемента пневмобалоном з автоматичним регулюванням жорсткості підвіски і формуванням іiі нелінійної пружної характеристики залежно від умов роботи підвіски (мікропрофіль ОП і динаміка перерозподілу навантажень на нього). Еволюційна сучасна активна підвіска є пневмогідравлічною з паралельною автоматикою регулювання пружинних характеристик пневмобалона, як пружного елемента і гідравліки, як демфуючого елемента - амортизатора. Це дозволяє сформувати нелінійні і пружні і демфуючі характеристики підвіски з автоматичним регулюванням під поперечні умови руху. Вказане за даними [16; 2628] підвищує середню швидкість руху бездоріжжям до 70\% у порівнянні до стандартних залежних ресорних підвісок у рамках збереженні допустимого рівня віброколивних навантажень на організм людини.

Актуальність і необхідність конструктивної реалізації нелінійних характеристик підвісок ВАТ 3 умов підвищення комфортності і динаміки руху бездоріжжям є предметом як вітчизняних [29-31] так і зарубіжних [32-35] досліджень.

Зокрема у дослідженнях [35] проведено ретельний огляд та аналіз понад 60 публікацій досліджень щодо формування характеристик регулювання активних і напівактивних підвісок, що засвідчує і про розгортання у 2017 році активних робіт у цій сфері у КНР. Аналогічним чином це стосується i розгортання робіт по конструктивному синтезу i дослідження незалежних підвісок ВАТ в Індії [35].

Окрім очевидних переваг регулювання активних і напівактивних підвісок військової автомобіль- ної техніки їхня реалізація, попри проблеми формування i оптимізації відповідних програм заходів регулювання характеристик підвіски в умовах бездоріжжя, має також і певні недоліки щодо звичних, пасивних механічних підвісок військової автомобільної техніки. Зокрема, це відчутне збільшення енергозатрат двигуна на привід пневмо- і гідросистем підвіски. Також спостерігається:

- підвищена вразливість такої підвіски з умов балістичного захисту;

- очевидна суттєво більша складність та вартість ремонту їі в експлуатації.

Очевидно, це є причиною домінуючого використання на машинах переднього краю перспективних модифікацій ТАК-4, фактично напівактивних, 3 механічними пружними або торсійними елементами 3 регульованими амортизаторами, що забезпечують певне компромісне рішення дилеми комфортності 3 одного боку, та мінімізації коливань навантаження у контакті шини з ОП - 3 іншого, що має значний вплив на прохідність та керованість машини.

Визначальна роль величини ходу підвіски під час руху бездоріжжям формується практично ймовірністю/частотою так зв. “пробою” підвіски і прямою передачею відповідних пікових вертикальних навантажень на кузов автомобіля та, відповідно на тіло водія із незначним зменшенням навантаження вібраційними і демпфуючими характеристиками сидіння. Водій рефлекторно обмежує максимальну швидкість руху бездоріжжям власне з умов дискомфорту відповідних вертикальних навантажень. Для наочності у табл. 2 представлено порівняльні характеристики ходів підвіски і максимальних швидкостей руху нових моделей військової автомобільної техніки армій США і РФ при узагальнені ряду публікацій $[1 ; 7]$ порівнянних повних мас ідентичних колісних формул, що отримані за результатами табл. 2.

Величина ходу підвіски має також вплив на досягнення відповідної максимальної швидкості руху бездоріжжям, оскільки “пробой” підвіски, що спричинює дискомфорт водія (екіпажу) наступає значно пізніше (табл. 2). Тому це зумовлено і відповідну активізацію робіт відомих виробників військових автомобілів, у т.ч. великотоннажних, щодо впровадження незалежних довгоходових підвісок на нових моделях колісної військової автомобільної техніки, зокрема:

- броньованого автомобіля WISENT (сімейство 2-,3-,4- вісних машин RMMV) виробництва німецьких Rheinmetall i MAN MilitaryVehicles з вищезгаданою підвіскою Тimoney першочергового сімейства GEFAS $(4 \times 4,6 \times 6,8 \times 8)$ (рис. 2$)$;

- броньованої машини (класу MRAP) Cougar 6×6 виробництва General Dynamics 3 ведучими осями 3 незалежною підвіскою Marmon-Heirrington конструктивно подібної до ТАК-4/ Timoney (рис. 3). 
Порівняльна оцінка сучасних моделей колісної ВАТ

\begin{tabular}{|l|l|c|c|c|c|c|c|}
\hline $\begin{array}{c}\text { № } \\
\text { 3/п }\end{array}$ & \multicolumn{1}{|c|}{ Модель } & $\begin{array}{c}\text { ВПК 3924 } \\
\text { Медведь }\end{array}$ & $\begin{array}{c}\text { Oshkosh } \\
\text { М-ATV }\end{array}$ & $\begin{array}{c}\text { БА3- } \\
69095\end{array}$ & $\begin{array}{c}\text { Oshkosh } \\
\text { MTVR }\end{array}$ & $\begin{array}{c}\text { БА3- } \\
690902\end{array}$ & $\begin{array}{c}\text { Oshkosh } \\
\text { LHS }\end{array}$ \\
\hline 1. & Колісна формула & $4 \times 4$ & $4 \times 4$ & $6 \times 6$ & $6 \times 6$ & $8 \times 8$ & $8 \times 8$ \\
\hline 2. & Повна маса, т & 12,8 & 14,0 & 30,0 & 26,3 & 39,0 & 35,3 \\
\hline 3. & Хід підвіски, мм & 300 & 508 & 260 & 406 & 280 & 406 \\
\hline 4. & Максимальна швидкість, & & & & & & \\
& км/год: & 110 & 105 & 70 & 105 & 70 & 105 \\
& - на шосе & & & & & \\
& - на бездоріжжі & 60 & 90 & $45-50$ & $80-90$ & $54-50$ & $80-90$ \\
\hline
\end{tabular}

Джерело: розроблено авторами за даними $[1 ; 5]$.

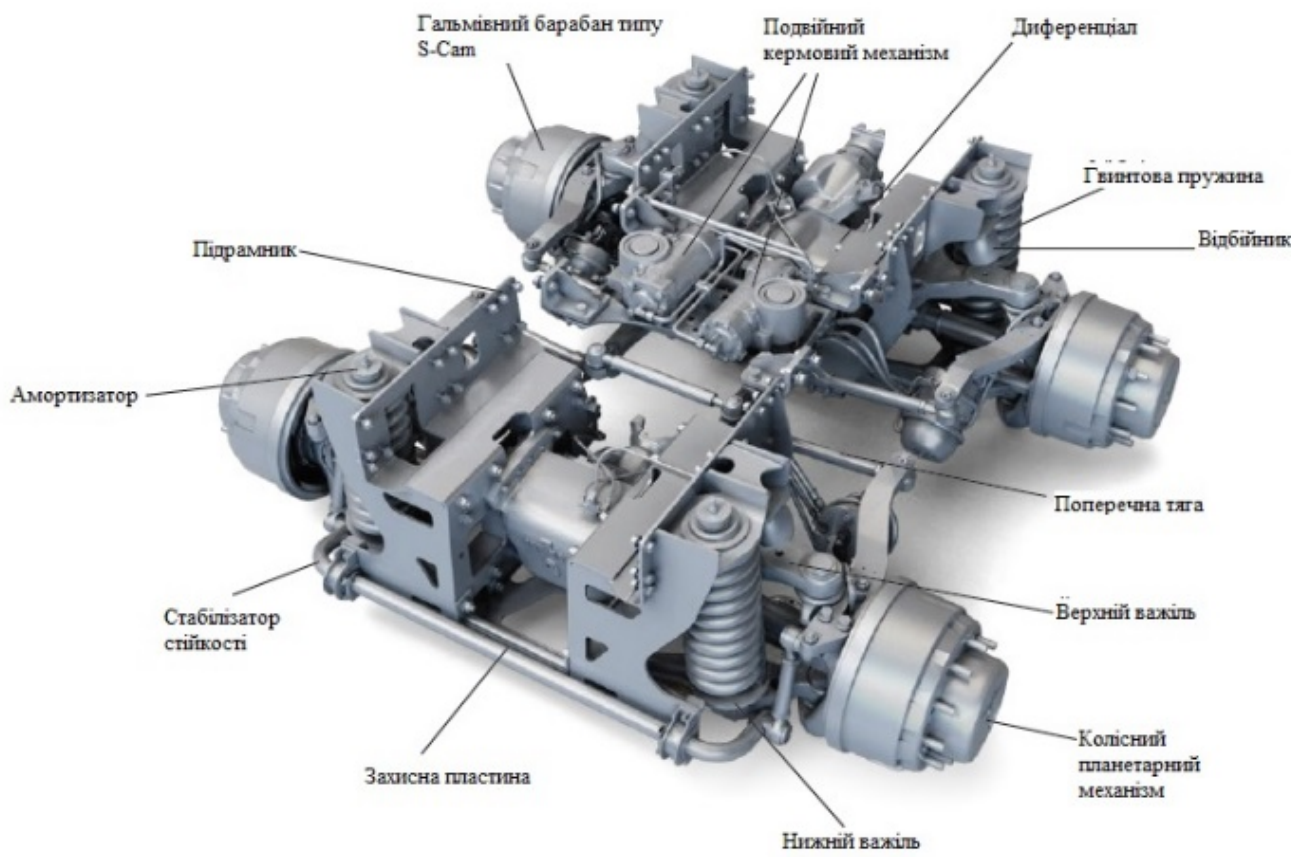

Рис. 3. Довгоходова незалежна підвіска Marmon-Heirrington конструктивно подібна до ТАК-4/ Timoney Джерело: розроблено авторами за даними [24].

Ця ж підвіска Marmon-Heirrington використана і на новому поколінню армійських автомобілів фінського виробника SISU.

\section{Висновки}

Аналіз даних конструкцій, як і сфери їхньої експлуатації, дозволяє констатувати наступне:

- однозначну тенденцію переходу практично в усіх категоріях тактичних автомобілів, насамперед колісних машин переднього краю, вогневої підтримки, інженерного та евакуаційного призначення, на довгоходові незалежні підвіски, що дозволяють суттєво зменшити непідресорені маси та, відповідно, вібронавантаженість кузова і екіпажу;

- 3 умов надійності конструкцій у складних умовах руху бездоріжжям, балістичного захисту i простоти ремонту у польових умовах поки доміну- ють механічні підвіски 3 сегментами кусковонеперервних функцій пружинних характеристик;

- очевидна тенденція впровадження, насамперед у спеціалізованих машинах переднього краю, вогневої підтримки переднього краю напівактивних підвісок з автоматичного регулювання демпфуючих або пружних характеристик підвіски;

- регулювання демпфуючих характеристик, що мають суттєвий вплив на вібронавантаженість, $є$ конструктивно легшим за рахунок відповідної автоматики амортизаторів, конструкції i промислове виробництво (у т.ч. для автомобілів загального призначення) та практично стає серійним компонентом підвісок нового покоління тактичних автомобілів;

- введення автоматики регулювання пружних характеристик підвіски з огляду на умови експлуа- 
тації військових колісних машин найбільш доцільно здійснювати на базі комбінованих пневмомеханічних підвісок, де пневмоелемент забезпечує лінійний характер пружної характеристики у певному діапазоні, а механічні пружні елементи (пружини, торсіони) - збереження рухливості машин при виході 3 ладу пнемо-підвіски.

Очевидно також, що 1,5-2 кратне збільшення ходів нового покоління незалежних підвісок обумовлює і особливу ретельність опрацювання суміщення кінематики підвіски 3 кермового приводу та стабілізації плями контакту шини з ОП.

\section{Список літератури}

1. Army Truck Program (Tactical Wheeled Vehicle Acquisition Strategy) Report to the Congress [Electronic resource]. Washington: Department of the Army, 2010. - 118 p. - Available at: https://apps.dtic.mil/dtic/tr/fulltext/u2/a536363.pdf.

2. Вержбицкий А.Н. Современные полноприводные колесные машины с независимой подвеской и осевой нагрузкой 7,0-11,5 тонн [Електронний ресурс] / А.Н. Вержбицкий, Г.О. Котиев, А.Б. Фоминых // Наука и инновации. 2013. - № 12. - Режим доступу: http://engjournal.ru/ catalog/machin/transport/1026.html.

3. DAF XF создан для дальних расстояний. - Режим доступу: http://www.dafchel.ru/trucks/xf/.

4. Шестаков В.А. Современные автомобили армий иностранных государств / В.А. Шестаков, А.А. Колтунов. Бронницы: НИИ Минобороны РФ, 2010. - 320 с.

5. Сибиляев М.К. Основные программы развития колесных машин многоцелевого назначения Сухопутных войск США на период до 2025 года / М.К. Сибиляев, В.А. Шестаков // Бронетанковое вооружение и техника, военная автомобильная техника в Вооруженных Силах Российской Федерации. - 2018. - № 1. - С. 50-54.

6. Шестаков В.А. Современный парк тактических автомобилей сухопутных войск США и перспективы его развития / В.А. Шестаков, Е.А. Голубенко // Вестник академии военных наук. - 2014. - № 2(47). - С. 134-141.

7. Шестаков В.А. Бронированые колесные машины армий зарубежных стран / В.А. Шестаков, А.А. Колтунов // Воскресенск: Воскресенская типография, 2013. - 382 с.

8. Плиев И.А. Автомобили многоцелевого назначения. Формирование технического облика АМН в составе семейств: монография / И.А. Плиев. - М.: МГИУ, 2017. - 262 с.

9. Сиренко В.Н. Иследование влияния плавности хода на эффективность использования боевых колесных машин по условиям жизнедеятельности екипажа: дис. ... канд. техн. наук / В.Н. Сиренко. - М., 1971. - 168 с.

10. Барков Ю.С. Влияние и изменения основных показателей боеспособности экипажа на боевую ефективность танка / Ю.С. Барков. - М.: Трун АВТВ, 1966. - 37 с.

11. Чутков К.А. Влияние колебаний боевых колесных машин на их боевую ефективность / К.А. Чутков, Н.О. Хренов // Журнал автомобильных инженеров. - 2017. - № 6(107). - С. 12-13.

12. Park S. Influence of soil deformation on off-road heavy vehicle suspension vibration / S. Park, A. Popov, D. Cole // Journal of Terramechanics. - 2004. - № 41. - P. 41-68. https://doi.org/10.1016 / j.jterra.2004.02.010.

13. Полугнян А.А. Проектирование полноприводных колесных машин / А.А. Полугнян. - М.: Издательство МГТУ им. Н.Э. Баумана, 1999. - Т. 1. - 488 с.

14. Грубель М.Г. Методологія оцінки опорної прохідності колісної військової автомобільної техніки / М.Г. Грубель, Л.В. Крайник, О.М. Купріненко // Озброєння та військова техніка. - 2019. - № 4(24). - С. $22-31$.

15. Грубель М.Г. Основні напрями розвитку середньотоннажних військових автомобілів / М.Г. Грубель, Л.В. Крайник, А.М. Андрієнко // Збірник наукових праць Харківського автодорожнього університету. - 2017. - № 40. C. 56-64. https://doi.org/10.30977/AT.2219-8342.2017.40.0.56.

16. Timoney E.P. Heavy vehicle independent suspension / E.P. Timoney, S.S. Timoney, S.G. Timoney // Proceeding of the IMechE “Advanced Suspensions”. - C434/88, 1988-9, P. 125-133.

17. Patent Evropean Patent Office VN 0287278 A vehicle chassis transverse structural member. - 1988/ Bul. № 88/42/ - 9 p.

18. Patent USA 2010/0156012 Hydro-pneumatic suspension system. - 2010. - 11 p.

19. Patent EPO №0706904 Improvements in independent suspensions. - 1994. - Bul. № 1996/16. - 13 p.

20. Patent US №8327966 Articulated dump truck. - 2012. - 19 p.

21. Patent US №2006019236 Suspension system. - 2006. -20 p.

22. Лещинский Д.Ю. Анализ перспективных конструкций систем подрессоривания транспортных средств на примере патентов мировых производителей [Електронний ресурс] / Д.Ю. Лещинский, А.А. Смирнов, Е.В. Ягубова // Наука и инновации. - 2013. -№ 12(24). - Режим доступу: http://engjournal.ru/catalog/machin/transport/1122.html/.

23. Офіційний сайт OREANDA.RU. KAMAZ Concluded Agreement with Timoney Technology Ltd. - Режим доступу: https://www.oreanda.ru/en/promyshlennost/article625086/.

24. Офіційний сайт PIERCEMFG.COM. ТАК-4 - Independent suspension brochure. - Режим доступу: https://www.piercemfg.com/tak-4-ifs/.

25. Illg. I.T. Mechatronic Design and Implementation of an Active Suspension for an All-Terrain Tracked Vehicle / I.T. Illg, M. Jäker, K.P. Trächtler // 9th International Symposiumon Advanced Vehicle Control (AVEC 2008). - 2008. P. 232-248.

26. Pyper M. ABC - Active Body Control: Von der Blattfederung zum aktiven System für mehr Fahrsicherheit und Fahr komfort / M. Pyper, W. Schiffer, W. Schneider. - Lanolsberg: Velog Moderac Industric, 2003. - 236 p.

27. Weisske A. Fully Active Suspension system for a Millitary All-Terrin Transport Vehicle / A. Weisske, V. Gel, A. Traechtler // 27th Applied Vehicle Technology Panel. - 2011. - Available at: https://www.hni.uni- 
paderborn.de/publikationen/publikationen/?tx_hnippview_pi1\%5Bpublikation\%5D=5623.

28. Дущенко В.В. Проблемы выбора параметров системы подрессоривания транспортных средств и пути их решения / В.В. Дущенко // Республиканская научно-практическая конференция "Системотехника на автомобильном транспорте". - Харьков, 1998. - С. 56-60.

29. Василенко О.В. Перспективи розвитку систем підресорювання військових гусеничних і колісних машин / О.В. Василенко, В.В. Дущенко // Механіка та машинобудування. - 2009. - № 1. - С. 163-174.

30. Грубель М.Г. Теоретичні засади формування параметрів підвіски колісної військової автомобільної техніки за умов руху бездоріжжям / М.Г. Грубель // Сучасні технології в машинобудуванні та транспорті. - 2019. - № 13(2). C. 52-62. https://doi.org/10.36910/automash.v2i13.87.

31. Bauer W. Hydropneumatische Federungssysteme / W. Bauer. - NewYork: Springer-Verlag, 2008. - 416 p. https://doi.org/10.1007/978-3-540-73641-7.

32. Шипилов В.В. Тенденции развития специальных колесных шасси и тягачей военного назначения / В.В. Шипилов // Информационно-технический сборник. - 2007. - 417 с.

33. Taghavifar H. Off-road Vehicle Dynamics / H. Taghavifar, A. Mardani. - NewYork: Springer-Verlag, 2017. - 183 p.

34. Comprehensive Analysis for Influence of Control lable Damper Time Delayon Semi-Active Suspension Control Strategies / YechenQin, Feng Zhao, ZhenfengWang, Liang Gu, Mingming Dong // Journal of Vibration and Acoustics. - 2017. № 139(3). - P. 12. - Available at: https://www.doc.org/10.1115/1.4035700.

35. Jagirdar V. Wishbone Structure for Front Independent Suspension of a Military Truck / V. Jagirdar, M. Dadar, V. Sulakhe // Defence Science Journal. - 2010. - № 2(60). - P. 178-183. https://doi.org/10.14429/dsj.60.337.

Надійшла до редколегії 30.01.2021

Схвалена до друку 02.03.2021

\section{Відомості про авторів:}

\author{
Манзяк Михайло Олександрович \\ провідний науковий співробітник \\ Національної академії сухопутних \\ військ ім. гетьмана П. Сагайдачного, \\ Львів, Україна \\ https://orcid.org/0000-0002-5634-9231
}

\section{Крайник Любомир Васильович} доктор технічних наук професор професор кафедри Національного університету

“Львівська політехніка",

Львів, Україна

https://orcid.org/ 0000-0002-0524-9126

Грубель Михайло Григорович

кандидат технічних наук доцент начальник кафедри

Національної академії сухопутних військ ім. гетьмана П. Сагайдачного, Львів, Україна https://orcid.org/0000-0002-4820-6935

\section{Information about the authors:}

\author{
Mykhailo Manziak \\ Lead Research \\ of Hetman Petro Sahaidachnyi \\ National Army Academy, \\ Lviv, Ukraine \\ https://orcid.org/0000-0002-5634-9231
}

\author{
Lybomyr Krajnyk \\ Doctor of Technical Sciences Professor \\ Professor of Department \\ of Lviv Polytechnic National University, \\ Lviv, Ukraine \\ https://orcid.org/ 0000-0002-0524-9126
}

Mykhailo Hrubel
Candidate of Technical Sciences Associate Professor
Head of the Department
of Hetman Petro Sahaidachnyi
National Army Academy,
Lviv, Ukraine
https://orcid.org/0000-0002-4820-6935

\title{
ТЕНДЕНЦИИ РАЗВИТИЯ КОНСТРУКЦИЙ ПОДВЕСОК ВОЕННЫХ АВТОМОБИЛЕЙ
}

\author{
М. Манзяк, Л. Крайнык, М. Грубель
}

В статье определены основные требования, которые влияют на развитие конструкиий образиов военной автомобильной техники (ВАT). В частности установлено, что с повышением скоростей движения и мобильности колесной ВАТ при движении по бездорожью в целом, влияют, как увеличение удельных мочностей двигателей, выбор оптимальных параметров трансмиссии, так и конструкции подвесок. Вибрационные и колеблющиеся нагрузки на водителя (экипаж) образиов ВАТ при движении по бездорожью формируют два определяющих аспекта применения автомобилей. Первый аспект связан с искусственным ограничением водителем скорости движения ниже максимальной технической из-за предельно допустимой границь его дискомфорта, а второй - через соответствуюшую усталость и существенное ухудшение моторики водителя (экипажа) в зависимости от продолжительности движения по бездорожью. Определены тенденции развития конструкиий подвесок, которые заключаются в переходе от зависимых подвесок с неразрезной балкой оси и жесткой взаимосвязью кинематики подвесок правого и левого колес к независимым. Такой подход позволяет обеспечить повышение комфортности в движении водителя и экипажа, а также повысить средние скоро- 
сти движения и существенно уменьшить поперечные крены кузова. Проведен анализ тенденций внедрения активных и полуактивной подвесок современных образцов колесной ВАТ, позволяющие существенно улучшить комфортность экипажа, сохранность груза и средние скорости движения. По результатам исследований установлена необходимость перехода на длинноходовые независимые подвески, для уменьшения неподрессоренных масс и вибронагрузки кузова и экипажа.

Ключевые слова: подвеска, колесная ВАТ, бездорожье, плавность движения, вибрационные нагрузки.

\section{TRENDS IN THE DEVELOPMENT OF STRUCTURES OF SUSPENSIONS OF MILITARY VEHICLES}

M. Manziak, L. Krainyk, M. Hrubel

In the article are defined the basic requirements influencing on development of constructions of military automobile equipment (MAE) samples. In particular, it was found that the increase in speed and mobility of the wheeled MAE when driving off-road in general, affect both the increase in specific power of engines, the choice of optimal transmission parameters and the design of the suspension. Vibrational and oscillating loads on the driver (crew) of the MAE samples while driving off-road form two defining aspects of the cars use. The first aspect is related to artificial limitation by the driver of high speed of motion below technical maximal through the maximum limit of his discomfort, and second - through a corresponding tiredness and substantial worsening of driver movement (crew) depending on duration of off-road traffic. The tendency of development of suspension designs is defined, which consists in transition from dependent suspension brackets with an inseparable beam of an axis and rigid interrelation of kinematics of suspension brackets of the right and left wheels to independent. This approach allows to increase the comfort for the driver and crew, as well as increase the average speed and significantly reduce the transverse center-punch of the body. The analysis of tendencies of introduction of active and semi-active suspensions of modern samples of wheeled MAE is carried out, which allow to significantly improve the crew comfort, safety of cargo and average speeds. According to the results of research is set the need to switch to long-running independent suspensions to reduce unsprung masses and vibration load of the body and the crew.

Keywords: suspension, wheel MAE, off-road, smoothness of movement, vibration loads. 